\title{
Kas-İskelet Sistemi Tümörlerinin Tanısında Ağrının Karakterinin Önemi: Olgu Sunumu
}

\author{
The Importance of Pain's Character on the Diagnosis of Musculoskeletal System \\ Tumors: A Case Report \\ Şule Şahin Onat, Neşe Özgirgin
}

Ankara Fizik Tedavi Eğitim ve Araştırma Hastanesi, Fizik Tedavi ve Rehabilitasyon Kliniği, Ankara, Türkiye

\section{Özet}

Kas-iskelet sistemi tümörleri sinsi ve sessiz kliniğe sahiptir, bu yüzden gözden kaçıılabilir. İstirahatte ortaya çıkan ağrı tümör açısından uyarıcıdır. Bu yazıda da istirahatte olan diz ağrısı dışında herhangi bir şikayeti olmayan hastada femur distal ucunda enkondrom tanısı alması sunulmuştur. (Türk Osteoporoz Dergisi 2014;20: 41-2)

Anahtar Kelimeler: Kas iskelet sistemi, tümör, ağrı karakteri

\section{Summary}

Musculoskeletal system tumors may be insidious and overlooked easily in the clinic. Rest pain can be the only sign and must need attention. A patient with resting knee pain is presented here who have been finally diagnosed as enchondroma of the distal femur. (Turkish Journal of Osteoporosis 2014;20: 41-2)

Key words: Musculoskeletal system, tumors, pain character

\section{Giriş}

Kemik tümörlerinin anatomik yerleşimleri, kökenleri, klinik bulguları ve davranışlarının farklılıklar göstermesi tanı güçlüğüne yol açmaktadır (1). Ayrıntılı bir anamnez ve tam bir fizik muayene yaparak ve radyografileri dikkatli inceleyerek bu güçlük aşılabilir. Bu yazıda da istirahatte olan diz ağrısı dışında herhangi bir şikayet ve bulgusu olmayan hastada femur distal ucunda enkondrom tanısı alması sunulmuştur.

\section{Olgu}

Elli altı yaşında erkek hasta son üç aydır sol dizde olan ağrı şikayetiyle polikliniğe başvurdu. Anamnezde hastanın ağrısının istirahatle arttığı, aktiviteyle azaldığı ve gece uykusundan uyandırdığı öğrenildi. Ağrısı VAS 8 düzeyindeydi. Travma, dizde kilitlenme ve hareket kısıtlılığı şikayeti yoktu. Özgeçmiş ve soygeçmişinde herhangi bir özellik bulunmamaktaydı. Yapılan muayenesinde her iki dizde eklem hareket açıklığı tam, ISı artışı, şişliği, patellar şoku bulunmamaktaydı. McMurray testi, Apley'in kompresyon ve distraksiyon testleri, valgus ve varus stres testi, ön ve arka çekmece testleri negatifti. Çekilen iki yönlü diz grafisi normaldi. Labaratuvar incelemesi normaldi. Bunun üzerine çekilen magnetik rezonans görüntülemesinde sol dizde femur diafiz lateralinde 21×11 mm boyutlarında enkondrom ile uyumlu lezyon olduğu tespit edildi (Şekil 1). Ortopedi kliniği ile konsülte edilen hastaya operasyon önerilmedi ve takibe alındı. Hastanın ağrısına yönelik nonsteroidal antiinflamatuvar ilaç verildi. Ağrısı VAS 4'e geriledi.

\section{Tartışma}

Enkondromlar kıkırdak kökenli tümörlerdir. Enkondrom, olgunlaşmış hiyalin kıkırdağın, tubuler kemiğin medüller boşluğundaki hamartomatöz kalıntı olarak kabul edilmektedir (2). Bu lezyon, büyüme kıkırdağının altında normal enkondral ossifikasyondaki bozukluktan kaynaklanmaktadır. Benign kıkırdak tümörleri içinde enkondrom en sık görülenidir (\%42) (3). Enkondromların \%40-\%70'i el ve ayaktaki ufak kemiklerde, geri kalanı da femur (\%10), humerus, tibia, fibula ve önkol kemiklerinde görülmektedir $(4,5,6)$. Enkondromlar, malign dejenerasyon riski sınırlı olan benign lezyonlardır. Lezyon $4^{\prime} \mathrm{cm}$ den büyükse, uzun kemiklerde tekrarlarsa maligniteye dönüşüm olasılı̆̆ vardır (7).

Yazışma Adresi/Address for Correspondence: Dr. Şule Şahin Onat, Ankara Fizik Tedavi Eğitim ve Araştırma Hastanesi, Fizik Tedavi ve Rehabilitasyon Kliniği, Ankara, Türkiye GSM: +90 5053136848 E-posta: sahinsulester@gmail.com Geliș Tarihi/Received: 05.08.2013 Kabul Tarihi/Accepted: 25.11.2013

Türk Osteoporoz Dergisi, Galenos Yayınevi tarafindan basılmıştır. / Turkish Journal of Osteoporosis, published by Galenos Publishing. 


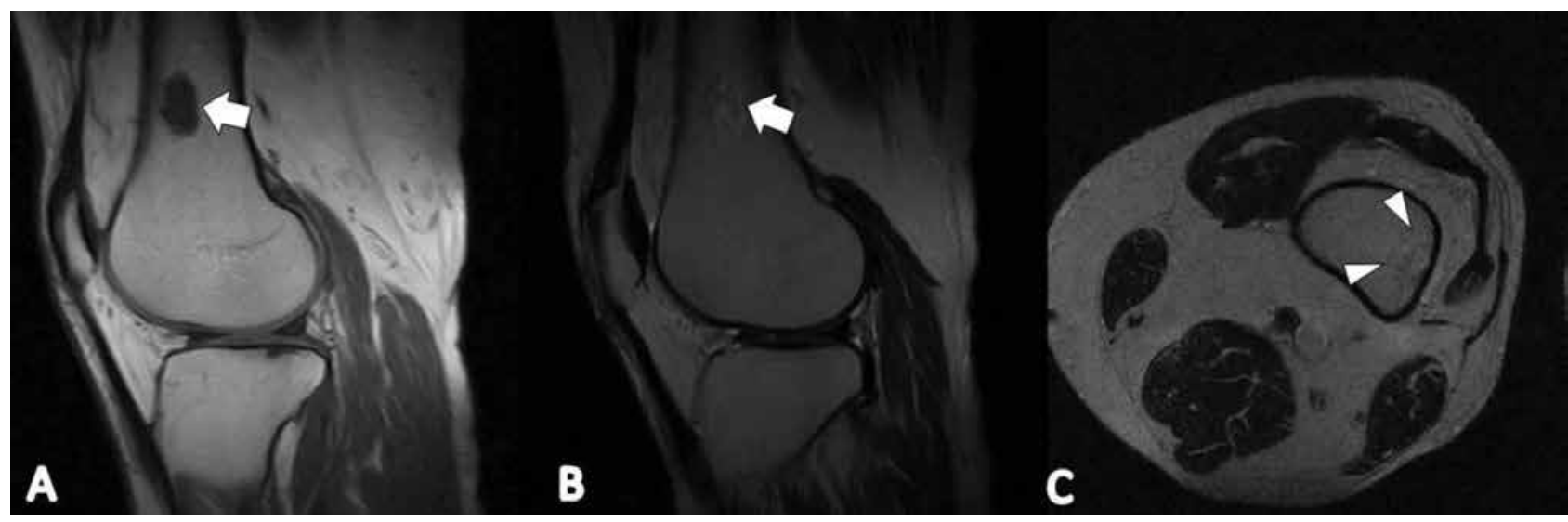

Şekil 1 A. T1 sagittal kesitte femur diafiz lateralinde hipointens lezyonun görüntüsü B. T2 sagittal kesitte femur diafiz lateralinde hiperintens lezyonun görüntüsü $\mathbf{C}$. T2 transvers kesitte hiperintens lezyonun görüntüsü

Enkondromlar genellikle ağrısız lezyonlardır $(2,8)$. Bizim olgumuzun istirahatte ve gece ağrısının olması ayırıcı tanıda tümör düşünmemize neden oldu. Kemiğin tümör ve benzeri lezyonları kas-iskelet sisteminin her yerini tutabilmektedir. Klinik davranışları, kendi kendine iyileşen hastalıklardan yoğun tedaviye rağmen hızla büyüyen ve kemiği harap eden, metastaz ve ölüme yol açan yüksek dereceli malign tümörlere kadar değişiklik göstermektedir. Klinik bulgular tam yerleştiğinde örneğin hasta patolojik kırıkla geldiğinde tanı koymak olağandır. Fakat olgumuzda olduğu gibi ağrının karakteri dışında herhangi bir ipucu olmadığında tanı koydurucu özellik ileri derecede şüpheciliktir. Bu gibi vakalarla kas iskelet sistemi semptomtolojisiyle uğraşan fiziyatristler için ayrıntıl alınan anamnezde ağrının karakterinin ısrarla sorgulanmasının önemi ortaya çıkmaktadır. Çünkü bu tümörlerde hafif rahatsızlık, ağrı, şişlik, kas-iskelet sistemi fonksiyon kaybı ve radyolojik değişiklik hekimler için uyarıcı olmamakta ve hastalardaki tümöral durumlar atlanabilmektedir (1). Hastalarda doğru tanı konulması tedaviyi değiştireceği için özen ister. Bizim olgumuzda lezyonun boyutu ve yerleşimi itibariyle cerrahi girişim düşünülmemiş ancak femur distalindeki enkondromların saptandıklarında takip ve gerekirse müdahale edilmesi gereken lezyonlar olduğu bildirilmiştir (2).

\section{Kaynaklar}

1. Ayvaz M, Aksoy MC. Kemiğin tümör ve tümör benzeri lezyonlarına yaklaşım. Hacettepe Tıp Dergisi 2006;37:124-31.

2. Adaş M, Yurdoğlu HC, Tonbul M, Özbaydar MU, Keriş i. Femur alt uç enkondromlarının küretaj ve kemik çimentosu ile tedavi sonuçları. Acta Orthop Traumatol Turc 2007;41:380-6.

3. Yücetürk G, Sabah D, Keçeci B, Kara AD, Yalçınkaya S. Kemik ve yumuşak doku tümörlerinin dağılımı. Acta Orthop Traumatol Turc 2011;45:135-43.

4. Yercan H, Ozalp T, Coşkunol E, Ozdemir O. Long-termresults of autograft and allograft applications in hand enchondromas. Acta Orthop TraumatolTurc 2004;38:337-42.

5. Campanacci M. Chondroma. In: Campanacci M, Bertoni F. Bacchini $P$, editors. Bone and soft tissue tumors. New York: Springer-Verlag; 1990. p. 213-29.

6. Nurboja B, Ward D, Patel K. Treatment of enchondroma pathological radial and ulnar fracture in a child with Ollier's disease. Injury Extra 2006;37:409-12.

7. Aksu N, Erdem MN, HIz VM. Bening Kemik Lezyonlarında Maligniteye Dönüşüm Belirtileri. TOTBID (Türk Ortopedi ve Travmatoloji Birliği Derneği) Dergisi 2007;6:3-4.

8. Bilgen MS, Tosun M, Yalçınkaya U, Çetin E, Salar N, Burgucu F. Soliter Enkondrom: Uzun Tübüler Kemik Yerleşimli Kıkırdak Lezyonu Olan 17 Olgunun Incelenmesi. Uludağ Üniversitesi Tıp Fakültesi Dergisi 2013;39:39-43. 